\title{
The Diversity of Religious Diversity. Using Census and NCS Methodology in Order to Map and Assess the Religious Diversity of a Whole Country
}

\author{
Christophe Monnot and Jörg Stolz
}

\section{Introduction}

Questions of religious diversity and pluralism are of great importance in Western societies and policies of diversity and pluralism must be based on a thorough empirical knowledge (Beckford 2003; Heelas and Woodhead 2005b). It is therefore no wonder that a large number of diversity and mapping studies have emerged in recent years. These often local, regional and qualitative studies have greatly extended our knowledge about questions of religious diversity and pluralism, but they are also plagued by various problems. They often study only small areas, give limited quantitative information about the religious groups, have limited comparability across religious traditions, treat only certain types of diversity and are mainly descriptive.

This chapter claims that studying religious diversity can be improved by using a combination of census and national congregations study (NCS) methodology. With this methodology, it is possible to study religious diversity in a comprehensive way across all religious traditions and in its organizational, geographic, structural, and cultural dimensions. We exemplify this claim by presenting both the state of the art of mapping studies in Switzerland and the added-value of the results produced by the first study with our research design in Switzerland and - for that matter - in Europe.

C. Monnot $(\bowtie) \cdot$ J. Stolz

Institute of Social Sciences of Religion, University of Lausanne, Anthropole, CH - 1015

Lausanne, Switzerland

e-mail: christophe.monnot@unil.ch; joerg.stolz@unil.ch 
In what follows, we first comment on the state of the art and then describe our new methodology in order to present a study using this framework to describe various types of religious diversity in Switzerland.

\section{State of the Art}

\section{Terminology: Diversity and Pluralism}

We make a distinction between a descriptive and a normative way of dealing with questions of religious diversity (Bouma 1997; Stolz and Baumann 2007). ${ }^{1}$ Religious plurality or diversity is used when describing a state of affairs in a valueneutral way. This plurality or diversity can be analyzed in organizational, geographic, structural, cultural (or other) dimensions. Religious pluralism, on the other hand, refers to normative ideas about the value of religious diversity; frameworks that accommodate and regulate religious diversity; or everyday interactions between individuals and groups in settings of religious diversity (Beckford 1999, 2003). In this chapter, we only look at the various dimensions of religious diversity - leaving the description of religious pluralism to other publications.

\section{Religious Diversity}

In what follows, we give a state of the art concerning the different types of studies that can be found on religious diversity in Switzerland (for an overview see Baumann and Stolz 2007; Bochinger 2012). Our goal is to use these studies as a backdrop to the kind of information we may obtain from the methodology we propose in this chapter. While we give the most important literature on Switzerland, we only point to some outstanding international literature on religious diversity.

A first type of publications consists of general overviews of religious diversity. In such publications, various religious traditions are treated, often in an "egalitarian" manner, describing the religious, cultural, structural and geographic attributes of different religions and religious groups. A Swiss example of such a publication is Baumann and Stolz (2007). This book also includes chapters on the historical development of religious diversity in Switzerland as well as on the relationship between religious diversity and various "societal subsystems". A second example is the book by Bochinger (2012) reviewing the results of National Research Program 58 . Books of this kind normally rely on secondary sources; their comparisons, while interesting, are of limited depth. Often, several experts on different religious

\footnotetext{
${ }^{1}$ See for a more general treatment of "diversity": Salzbrunn (2012).
} 
traditions collaborate to publish such a book, leading to a pooled expertise, but also creating specific problems (see below). Well-known international publications of this kind are Eck (2001) for the USA, Bouma et al. (2010) for Asia and Australasia, Ferrari and Pastorelli (2012), Pollack (2008), Vertovec (2007) and Willaime (2004) for European countries.

Second, we find publications using official statistical data. Authors of such texts use various official statistical sources in order to describe religious diversity. In Switzerland, Bovay (1997) is such a text, providing information on religious membership since 1900, based on Swiss census data. Husistein (2007) is another example, using official Catholic statistics in order to shed light on internal Catholic diversity.

Third, there are so-called mapping studies. Authors of such studies normally work on a limited geographic area, try to locate all the existing places of worship for a single religious tradition or for several or all of the traditions, and visit these places or conduct a qualitative description of the places and communities found. In Switzerland, we find such mapping studies for the city of Zurich (Humbert 2004), the city of Basel (Baumann 2000), and the canton of Ticino (Trisconi di Bernardi 2006). A project at the University of Lucerne continually maps religious diversity in the canton of Lucerne ${ }^{2}$ and Rademacher (2007) has mapped spiritual groups and new religious movements in the city of Bern. Such mapping studies are extremely useful in getting a sense of the sheer complexity of groups in a certain area. On an international level, one of the first important studies of this type is that directed by Cnaan in Philadelphia. This contributed to the identification of 2,095 different communities in this city (Cnaan and Boddie 2001). In the United States, other surveys were subsequently conducted, such as the one by the United Way of Delaware, which inventoried 100 communities in Wilmington (Cnaan and Wineburg 2009) or the one made in a county of Michigan: the Kent County Congregations Study (KCCS), which identified 720 groups in this area (Hernández et al. 2008). In Europe, two groundbreaking projects based on congregation mapping must be mentioned. The first was conducted in England at Kendal, a town of fewer than 30,000 inhabitants, by Heelas, Woodhead and their collaborators, who visited the groups that they defined as the "congregational domain" and those of the "holistic milieu" (Heelas and Woodhead 2005a, b; Woodhead et al. 2004). Hero, Krech, and their collaborators conducted another large scale project in Germany to identify the religious communities in the state of West Rhine-Westphalia (Hero et al. 2008). Other surveys have been or are now in process in European cities, such as Turku in Finland (Heino 1997; Martikainen 2004); the Aarhus area in Denmark (Ahlin et al. 2012) ${ }^{3}$; or again in Great Britain in the context of the Community Religion Project. ${ }^{4}$

\footnotetext{
${ }^{2}$ http://www.religionenlu.ch

${ }^{3} \mathrm{http}: / /$ teo.au.dk/en/csr/religionindenmark/

${ }^{4}$ http://arts.leeds.ac.uk/crp/
} 
A fourth kind of text analyzes the evolution of religious diversity concerning specific religious traditions, often in regards to migration. In Switzerland, we find many such studies. Some examples are the studies by Baumann $(2004,2009)$ on the Tamil and Hindu diasporas in Switzerland, the texts by Behloul (2012a, b) on Muslims from the former Yugoslavia in Switzerland or the work edited by Monnot (2013a) on the institutionalization of Muslim organizations. Well-known international studies include the survey by Knott (2009) on Hinduism in Great Britain, the book by Kay and Dyer (2011) on European Pentecostalism, and the studies on the transformations and influences of Islam in Europe (Al-Azmeh and Fokas 2007; Frégosi 2008; Göle 2011).

\section{General Problems and Issues}

We think that both the Swiss and the international studies mentioned have been very useful and have greatly extended our knowledge of religious diversity. However, there are a certain number of shortcomings in many of them. While the first two types mentioned - general overviews and official statistics - give an overall picture of religious diversity, their comparisons are often very limited and lack a certain depth. This depth is often found in the third and fourth types - the mapping studies and the combination of studies concerning specific traditions - but these studies have at least four other drawbacks:

1. They normally study a relatively small geographic region. Emerging from them is an overall picture rather like Google maps: certain areas are very precise, with a wealth of ethnographic data, while other areas are very pixilated. Some cities or neighborhoods are richly documented while others are not investigated at all, thus limiting a general representation of the situation.

2. Limited quantitative information. Many mapping studies are inherently qualitative, often relying on participant observation, interviews and documentary analysis. While this is certainly very useful information, many interesting questions about religious diversity require quantitative measures that are consistently applied to all the studied groups.

3. Limited comparability. This third point is linked to the second. When different religious groups are investigated with qualitative methods by different researchers, the results are often difficult to compare. They are rarely based on the same definitions of the object of study, which is here the religious community. We also find in quite a few mapping studies that experts on certain religions collaborate, each expert working on "his" or "her" religion. However, the problem then arises that the ways in which the religious traditions are studied vary, because different experts adopt different positions, requiring distinctive methodologies. Of course, this leads - once again - to limited comparability among religious traditions. 
4. Inapplicability to different types of diversity. It also appears that existing mapping studies often treat only certain types of diversity, while neglecting others. It is rare that organizational, geographic, structural, and cultural diversity are investigated systematically across religious traditions.

5. Inability to lead to theory testing. Finally, mapping studies are normally purely descriptive, refraining from an explanation of the regularities observed. This is due, on the one hand, to the methodological inclinations of the researchers; on the other hand, however, it is also true that the data gathered from mapping studies are seldom structured and complete enough to allow for systematic explanation.

Our claim in this chapter is that a number of problems of all four types of studies may be overcome - at least in part - with the methodology presented here. We of course do not suggest that all studies on religious diversity should be abandoned in order to do national congregations studies. Rather, we think that the study here presented complements the existing ones very usefully, putting the latter into a larger context and rendering scattered information comparable.

\section{A New Approach: The NCS Method}

To gain an overview with parameters permitting the sociological comparison of local groups and communities, an important 3-year study was carried out in Switzerland. Modeled on the survey of the NCS (conducted in the United States in 1997-1998, and then conducted in a second wave in 2006-2007 under the direction of Chaves (2004; Chaves and Anderson 2008), a major study has recently been set up in Switzerland (Stolz et al. 2011). A notable difference with the American study resides in the fact that, in Switzerland, a mapping of all the active congregations has been undertaken.

\section{Defining and Operationalizing Congregations}

We define the term "congregation" as: "a social institution in which individuals who are not all religious specialists gather in physical proximity to one another, frequently and at regularly scheduled intervals, for activities and events with explicitly religious content and purpose, and in which there is continuity over time in the individuals who gather, the location of the gathering, and the nature of the activities and events at each gathering. This distinguishes congregations from other religious social forms such as monasteries or denominational agencies, which are constituted mainly, perhaps exclusively, by religious specialists; religious television and radio productions, whose audiences are not in physical proximity to one another; seasonal celebrations, holiday gatherings, and other religious 
assemblies that may occur at regular but infrequent intervals; rites of passage, corroborees, and other events that occur neither frequently nor at regular intervals; and camp meetings, post-game prayer circles, pilgrimages, religious rock concerts, passion plays, revivals, and other religious social forms that lack continuity across gatherings in participants, location, or content of activities" (Chaves 2004: 1-2). This definition covers the groups historically established in Europe, as well as those in the process of implantation; it does not differentiate groups according to a typology, but as specific organizational units regardless of the denomination, the religious tradition or the cultural history of the group.

But is it really possible to apply the notion of "congregation" to non-Christian religions? Here, it is important to bear in mind the exact definition given above. In our view, Christianity, Judaism and Islam may clearly be seen as congregational in modern societies, but even religious traditions that elsewhere are not organized congregationally, such as Hindu traditions or Buddhism, tend to take this form when they try to survive in the diaspora in Western countries. As Ammerman (2005: 3) noticed: "there are common patterns in how people have chosen to gather". The organization of the diaspora pushes religious expression in a congregational direction. This trend was first called "de facto congregationalism" by Wind and Lewis (1994). In Europe, the specialists have identified the same tendency towards a "congregationalization" or a "templeisation" as an effect of the diasporas. For example, Baumann observes that "Tamil Hindus in Germany and Switzerland have been eager to establish collective places of worship, starting with small sites in basements and private rooms, and gradually moving on to much more spacious halls for worship and social gatherings" (Baumann 2009: 166). Thus, we argue that we find in many religious traditions "local communities" or "congregations" as we have defined them above, and that it is feasible to include them in our comprehensive list, if they conform to the definition.

\section{Conducting a Census}

We conducted a census from September 2008 to September 2009, counting all local religious groups in Switzerland. This was done by combining all sources of information we could find, such as:

- existing lists of local religious groups by Churches and Federations

- existing lists (published or not) by scholars of religion

- existing lists appearing on institutional internet sites, directories or databases

- data collected from the terrain with, notably, snowball sampling and indications from informers within the religious milieus.

We combined all this information, finely filtering the types of organizations so as to identify only the local religious groups (congregations). Each entry on the final list was checked by two independent sources of information. 
Of course, a certain number of hybrid phenomena exist and, accordingly, we had to develop specific rules of decision for "difficult cases" (Marzi 2008). These rules were based partly on the criteria to distinguish a religious organization described by Jeavons (1998) and the definition of religion given in Stolz (2010: 7).

\section{Conducting a Representative Survey of Congregations}

In the second phase of our study, we drew a representative sample of 1,040 religious communities in Switzerland, starting from the census report. The existence of the census data allowed us to stratify our sample and to overrepresent religious minority groups. This is why our data let us compare local religious groups across both majority and minority traditions. For every chosen congregation, one key informant (in most cases the spiritual leader) was interviewed by telephone (CATI) in one of the three national languages. A closed question questionnaire was used that was adapted from the American counterpart (Chaves and Anderson 2008). ${ }^{5}$ Special care was taken to adapt the questionnaire to Swiss conditions and the whole range of religious traditions.

In order to avoid well-known types of bias in key informant studies, the approximately 250 questions were centered on concrete and verifiable practices as well as on the tangible characteristics of the organization for which the respondent could provide reliable information (Chaves et al. 1999: 463-465; McPherson and Rotolo 1995: 1114). The various religious federations supported the project by encouraging the local leaders to take part in the inquiry, thus producing a response rate of $71.8 \% .^{6}$

\section{Assessing the Diversity of Religious Diversity: Organizational, Geographic, Structural, and Cultural Comparisons}

In what follows, we show that the combination of a census and a NCS is able to capture social/organizational, geographic, and cultural diversity in a comprehensive way, thus avoiding the "Google map problem" of only selective precision. We illustrate these claims with various examples.

\footnotetext{
${ }^{5}$ For the adaptation of the questionnaire, we refer to Behling and Law (2000); Forsyth et al. (2007).

${ }^{6}$ The response rates correspond to RR1 calculated according to the standards defined by the AAPOR (2011).
} 


\section{Organizational Diversity: 5,734 Congregations}

Our data allows us to give exact statistical information on the number and percentages of local religious groups in Switzerland, that is, social/organizational diversity (Table 1). From September 2008 to September 2009, we identified 5,734 local religious groups active on the Swiss territory. The census survey lets us first observe Christian diversity. We counted 1,750 Catholic communities (30.5\%) and 1,094 Reformed parishes (19.1\%). 1,423 congregations are Evangelical, representing one-quarter of the local groups. All other Christian traditions have a much smaller percentage of local religious groups. The one big surprise in this list is the very high number of Evangelical congregations. The evangelical milieu in Switzerland makes up only about 2-3\% of the population, but it produces about a quarter of all congregations! The obvious explanation is that Evangelical local groups are all rather small in comparison to, say, Roman Catholic or Reformed groups.

Almost one out of five communities in Switzerland (17\%) has its roots in a tradition that is not Christian. If one-third is linked to Islam $(5.5 \%),{ }^{7}$ let us highlight the internal diversity of these groups: they include Sunni communities (Hanefites, Malechites, Hanbalites, Shafiites); Sufi communities; Shi'as of various traditions such as the Alevis, the Ismaelians, etc.; and a number of groups considered as dissident by Sunni Islam, such as the Ahmadiyya, who built the first mosque in Switzerland in Zurich, and the Abashes, who have the main mosque in Lausanne (Monnot 2013a: 33).

For the other non-Christian collectivities, the groups are very varied, too. For Buddhism (2.5\%), let us note that the first Tibetan monastery in Europe was founded in Switzerland, at Rikon, then a second near Montreux. Both the traditional Buddhist currents (Theravada, Mahayana, Vajrayana, Zen) and the neo-Buddhist ones are present in communities in Switzerland. The same is true of Hinduism (3.3\%), with both the traditional groups, such as the Tamil temples, and the Neo-Hindu groups, such as Hare Krishna (ISKON, six groups), Yoga (Sahaja, self-realization, etc. $0.5 \%)$, and Transcendental Meditation $(0.2 \%)$. We also count groupings of Sikhs $(0.8 \%)$, Baha'is $(0.7 \%)$, as well as various communities $(4.5 \%)$ including esoteric groups $(1.1 \%)$, Spiritualism $(0,8 \%)$, Scientology $(0.5 \%)$, six circles of Grail movement and many more besides.

\section{Geographic Diversity: The Urban-Rural Gap}

Our methodology can also describe the geographic religious diversity in Switzerland. Geographical religious diversity is not distributed homogeneously over the national territory; it mainly concerns the cities. This can be seen, first, by looking at common measures of diversity on the basis of the number and size of different

\footnotetext{
${ }^{7}$ For one-half of the regular non-Christian worshipers.
} 
Table 1 Distribution of congregations by religious tradition

\begin{tabular}{lrr}
\hline & \multicolumn{2}{c}{ Congregations in Switzerland (2008) } \\
\cline { 2 - 3 } Religious tradition & \multicolumn{1}{c}{$\mathrm{N}$} & \multicolumn{1}{c}{$30.5 \%$} \\
\hline Roman Catholic & 1,750 & $0.6 \%$ \\
Christ Catholic & 35 & $19.1 \%$ \\
Reformed & 1,094 & $24.8 \%$ \\
Evangelical & 1,423 & $1.0 \%$ \\
Orthodox & 58 & $7.0 \%$ \\
Other Christian & 399 & $0.6 \%$ \\
Jewish & 33 & $5.5 \%$ \\
Muslim & 315 & $2.5 \%$ \\
Buddhist & 142 & $3.3 \%$ \\
Hindu & 189 & $5.2 \%$ \\
Other religions & 296 & $\mathbf{1 0 0 . 0} \%$ \\
Total & $\mathbf{5 , 7 3 4}$ &
\end{tabular}

Source: NCS, University of Lausanne 2008

traditions. Using the Herfindahl-Hirschman Index, we find that the supply of congregations is "moderately concentrated" with an index at 2035.

Second, we see that cities are also much more diverse in that they have the most non-Christian and non-established groups (Fig. 1). In the cities, we find $31 \%$ of non-Christian groups: Buddhists, Hindus, Jews, Muslims, New Religious Movements and others $11 \%$ of Other Christians (e.g. Lutherans, Anglicans, messianic congregations: Jehovah's Witnesses, Latter Day Saints, New-Apostolics, etc.) and $32 \%$ of Evangelicals - leaving only $26 \%$ to the established Christian groups. In rural areas, on the other hand, we find only relatively small percentages of non-Christians (5\%), other Christians (5\%) and Evangelicals (17\%). $74 \%$ of all the groups belong to the established Churches: Roman Catholics and Reformed.

The rural areas show a traditional profile, with an important supply (in relation to the number of inhabitants) in the two historical denominations. The more urban is the geographic space, the greater is the diversity. In the city, on the one hand, Christianity is fragmented into small groups of different denominations and, on the other, non-Christian communities can find room to become established. Several reasons for these disparities can be cited. Historically in Switzerland, the city was the most suitable place for the Reformation, opening the door to Protestant diversity. More recently, the city has been the favored environment for migration (Wihtol de Wenden 2004). Since the beginnings of the Chicago School with The City by Park et al. (1925) or - as far as migration and religious communities are concerned - The Ghetto by Wirth (1928), we know that the city plays a central role in the absorption of migration. With our methodology, we can measure the impact on religious diversity and thus better understand the disparities in order to document the different dynamics that stem from it. 


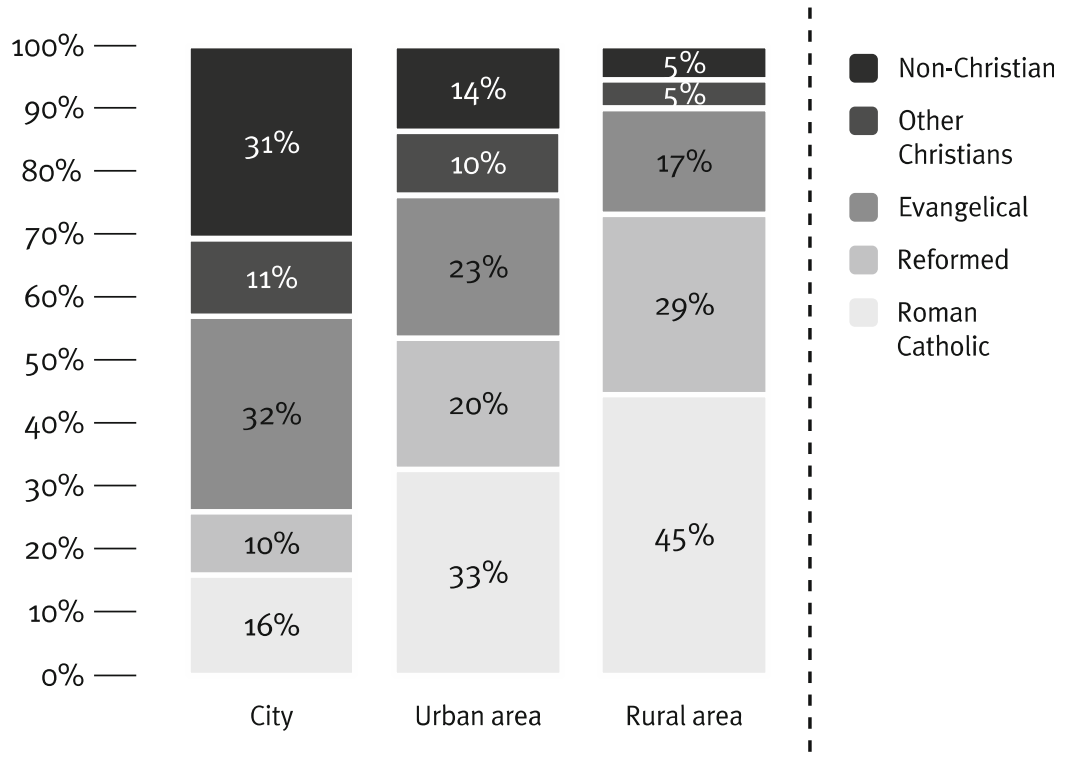

Fig. 1 Types of denominations according to the urban/rural characteristics of the areas (Source: NCS, University of Lausanne 2008)

\section{Structural Diversity: Buildings, Wealth and Staff, Membership}

Our methodology also lets us analyze religious diversity in the social/structural dimension. This dimension is often neglected in texts on religious diversity. However, it is of utmost sociological importance. In our study, we were able to reduce the complexity of religious groups to four large profiles: the recognized communities, the non-recognized Christian communities, the non-Christian congregationalist communities and "spiritual" groups organized as networks.

These different profiles were arrived at by inductive analysis of various kinds but they can best be presented as following from three distinctions (Monnot 2013b) (Fig. 2).

First, we distinguish local religious groups that are established (State recognized) from those that are not established. In the first group, we find Reformed and Catholic churches. They enjoy a public recognition in most cantons (the exact effects of recognition vary $)^{8}$ and their local groups enjoy administrative, legal and fiscal advantages that the other groups do not have.

Second, and among the non-established groups, we distinguish those that are Christian and those that belong to other religious traditions. Historically, the associative forms of Western society have influenced the Christian institutions.

\footnotetext{
${ }^{8}$ See for the details: Pahud de Mortanges (2007) In some cantons, other religions may also be recognized.
} 


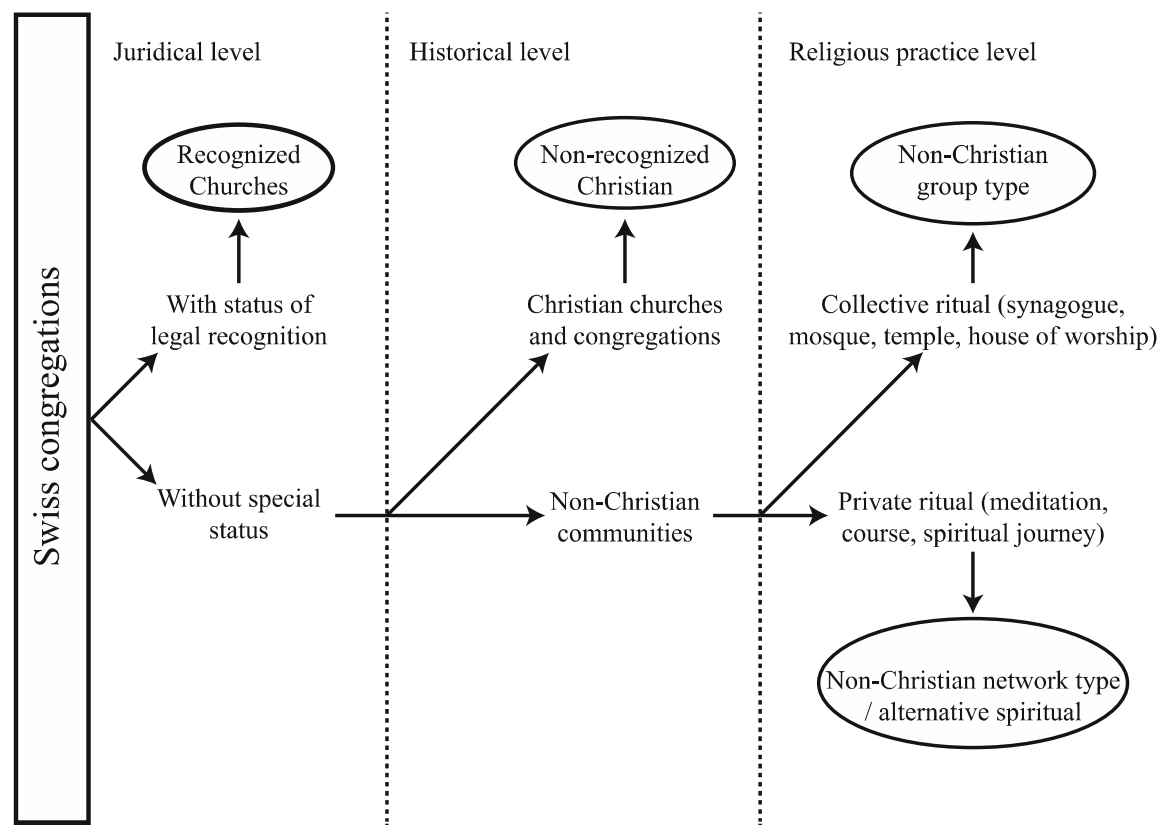

Fig. 2 Four structural profiles (Source: NCS, University of Lausanne 2008)

Third, and among the non-Christian groups, we distinguish on the one hand groups whose religious traditions are based on a collective and organized ritual such as the Jews and the Muslims, the Buddhist temples, the Hindu temples connected with the diaspora (Baumann 2009; Baumann et al. 2003; Knott 2009) and, on the other hand, groups favoring networks and an alternative and individual spirituality, close to that which Heelas and Woodhead (2005a) have named the "holistic milieu".

Together, the three nested distinctions thus lead us to the four profiles that we will now briefly describe. Our claim is that these four profiles make sense of much of the structural diversity of local religious groups in Switzerland. As Table 2 shows, the first is constituted by the historical, majority and state-recognized Churches, founded on average before the seventeenth century. The communities of this category meet in dedicated religious buildings that, very often, they own (or have the right to use) and that benefit from historic preservation. These groups have many members; they have a high income and provide their universityeducated leader with a comfortable salary, full-time in three-fourths of cases. The worshipers meet in a community close to their homes. The audience there is old and much feminized. An interesting aspect to point out here is the relatively low rate of education/awareness training of the children in the community context. This rate reflects the strong institutionalization of the groups rather than a weak following among the youth. In fact, their status allows them, in more than one-third of cases, to provide religious education within the school system. Moreover, the parishes are 
Table 2 Four large institutional profiles

\begin{tabular}{|c|c|c|c|c|}
\hline Mean & $\begin{array}{l}\text { Recognized } \\
\text { Churches }\end{array}$ & $\begin{array}{l}\text { Non- } \\
\text { recognized } \\
\text { Churches }\end{array}$ & $\begin{array}{l}\text { Non-Christian } \\
\text { group type }\end{array}$ & $\begin{array}{l}\text { Non-Christian } \\
\text { network type }\end{array}$ \\
\hline \multicolumn{5}{|l|}{ History and Building } \\
\hline Founded (year) & 1690 & 1940 & 1975 & 1984 \\
\hline $\begin{array}{l}\text { Historic preservation of the } \\
\text { building }\end{array}$ & $74 \%$ & $17 \%$ & $20 \%$ & $7 \%$ \\
\hline Religious building & $98 \%$ & $59 \%$ & $35 \%$ & $6 \%$ \\
\hline $\begin{array}{l}\text { Rent premises for religious } \\
\text { practice }\end{array}$ & $3 \%$ & $34 \%$ & $46 \%$ & $64 \%$ \\
\hline \multicolumn{5}{|l|}{ Wealth and Staff } \\
\hline $\begin{array}{l}\text { Annual income of the con- } \\
\text { gregation }(\mathrm{CHF})\end{array}$ & $850 ’ 000$ & $220^{\prime} 000$ & $110^{\prime} 000$ & $13 ’ 000$ \\
\hline $\begin{array}{l}\text { Annual salary of the leader } \\
\text { (full-time in CHF) }\end{array}$ & $91 ’ 000$ & $42{ }^{\prime} 000$ & $24 ’ 000$ & 0 \\
\hline Paid spiritual leader & $98 \%$ & $62 \%$ & $43 \%$ & $4 \%$ \\
\hline Full-time spiritual leader & $70 \%$ & $45 \%$ & $32 \%$ & $0 \%$ \\
\hline $\begin{array}{l}\text { Paid staff (part and full- } \\
\text { time) }\end{array}$ & 7 & 2 & 2 & 0 \\
\hline $\begin{array}{l}\text { University education of the } \\
\text { leader }\end{array}$ & $98 \%$ & $60 \%$ & $63 \%$ & $15 \%$ \\
\hline Age of the leader (years) & 51 & 49 & 47 & 54 \\
\hline$\%$ of female spiritual leaders & $12 \%$ & $8 \%$ & $9 \%$ & $50 \%$ \\
\hline \multicolumn{5}{|c|}{ Members } \\
\hline $\begin{array}{l}\text { Affiliated members (theo- } \\
\text { retic median }{ }^{\mathrm{a}} \text { ) }\end{array}$ & 1,400 & 75 & 270 & 16 \\
\hline Regular attendants (median) & 90 & 80 & 60 & 15 \\
\hline Female regular attendants & $66 \%$ & $57 \%$ & $42 \%$ & $64 \%$ \\
\hline $\begin{array}{l}\text { Regular attendants aged } \\
60 \text { and more }\end{array}$ & $58 \%$ & $29 \%$ & $22 \%$ & $20 \%$ \\
\hline
\end{tabular}

Source: NCS, University of Lausanne 2008

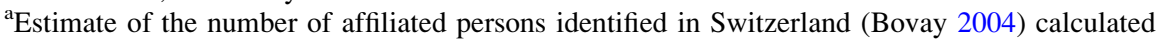
from the number of persons having a "link" to a congregation (NCS, University of Lausanne 2008)

interlinked with the Churches that organize or centralize certain services such as catechism.

The non-recognized Christian congregations were mostly founded in the nineteenth and twentieth century (mean: 1940). A little more than one-third of the groups rent their premises because they do not possess any. The annual income of the communities is four times lower than that of the recognized Churches. The spiritual leaders work as volunteers in four communities out of ten and a little less than half are employed full-time for a salary of about 42,000 CHF. ${ }^{9}$ In six cases out of ten, the leaders have had a university education. In these groups, the median number of regular worshipers corresponds to the number of affiliated persons,

\footnotetext{
${ }^{9}$ CHF: Swiss Francs. The average Swiss salary is 60,000 CHF (FSO 2012: 19).
} 
indicating thereby that a member is almost automatically an active person in the community, which is not the case for members of the recognized congregations. The members must travel a little further to practice, but the majority nevertheless resides less than 10 min away. Contrary to the preceding group, the local community strongly organizes the religious education of the children.

The profile of non-Christian groups based on a collective ritual resembles that of the non-recognized Christian communities, since legally they are on the same level. However, the non-Christian congregations are distinguished by a greater instability and recency of the group with a strong foreign presence: only one celebration out of five is given in the language of the linguistic region. Founded on average late in the twentieth century, these communities, in four cases out of ten, do not own premises in which to meet. The average income is circa $110,000 \mathrm{CHF}$ and one-third remunerates a spiritual leader. Another point to bring out is their relative similarity with the recognized Churches regarding the number of affiliated members, very much higher than that of the regular worshipers, since the latter represent about one-fifth of the affiliated. A particularity to note here is the relatively high proportion of men who regularly attend the religious ceremonies. This element depends on traditions and theological elements, in Islam and in Judaism, which strongly differentiate religious practices according to gender.

The final profile assembles smaller, more recent groups, meeting in premises that are "not religious", sometimes in centers shared by several groups (alternative spirituality). Their leadership is mainly voluntary since only one group out of ten provides a leader with a salary, and is strongly feminized since a woman directs almost one group out of two. The latter point distinguishes these groups very clearly from the others, since only the recognized Churches and especially the Reformed Church have more than one group out of ten with a female spiritual leader. In groups of the holistic milieu, the number of affiliated members corresponds to that of the regular members, who travel much more than do members of the other groups to get to the place where the main spiritual activities occur. The members, who are mostly adult women, attend these groups in order to experience well-being, develop their personality, and grow spiritually. In this sense, another important point to highlight is that the communities of this category are clearly distinguishable from the others by the absence of the transmission to and education of children. The center of attention is thus the adult member. This category corresponds, at the institutional level, to the "holistic milieu" of Heelas and Woodhead (2005a) or Mayer (1993).

\section{Cultural Diversity: Worship Modalities}

Our methodology further lets us compare the groups on the cultural level. Qualitative studies often analyze this type of diversity, but seldom succeed in comparing it across religious traditions; in quantitative studies, cultural diversity is rarely measured. 
In the following, we show religious diversity concerning celebrations across religious traditions.

As could have been expected, religious celebrations in Switzerland vary greatly according to religious traditions - our methodology, however, lets us estimate for the first time just how much they differ on both a number of general dimensions and very specific attributes.

Take, for example, the length of the religious service. In Fig. 3 we see that Roman Catholics have, on average, the shortest religious services (54 min), while Orthodox groups clearly have the longest services (more than $200 \mathrm{~min}$ on average). Other religious traditions fall between these extremes. However, we can compare not only the absolute length of the religious service - but also the relative length of various internal components. Thus, we can see from Fig. 3 that Reformed services are much shorter than Orthodox services - but that they give the same amount of absolute time to the sermon - about 15-16 min. Another way to say this is that the sermon is relatively more important to the Reformed tradition. Again, this is what we would have expected - but here we can (we think for the first time) estimate the differences.

Let us go a bit deeper into the description of the four domains of ritual elements that we distinguish in religious services across traditions:

\section{Prayer}

Concerning meditation, prayer and liturgical acts, the non-Christian groups distinguish themselves by a major portion for this type of element, which represents more than $50 \%$ of the time of celebration. For the Christians, this element also remains close to one-half of the celebration time. The groups with Protestant roots spend less time on ritual and on prayer, but more on preaching. This is the opposite for the Roman Catholics or the Christian Catholics. For the Orthodox, let us point out further that the priest accomplishes a major part of the ritual by singing, thus blending two elements that remain much more separate in the other denominations.

\section{Music}

The portion of music is also very diverse. The Christian groups all spend between 20 and $30 \%$ of the celebration time on music (with the exception of Orthodox worship with more than $60 \%$ of the celebration sung). On the other hand, for the non-Christian communities the time for singing or music is minor, since the groups generally do not sing for more than $10 \%$ of the celebration time, with the exception of the Jewish groups; Hindus, who devote $40 \mathrm{~min}$ to music and 


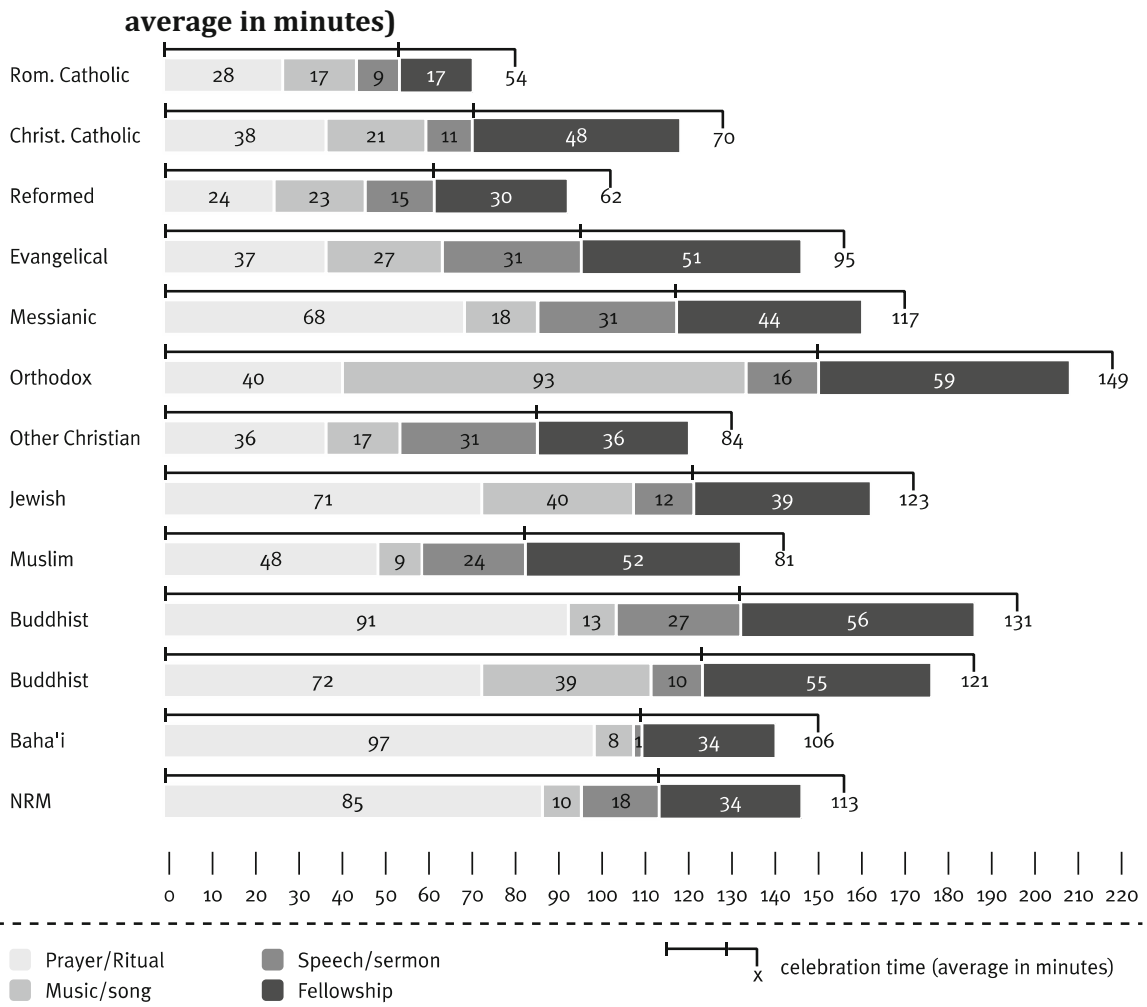

Fig. 3 Time of prayer, music, sermon and fellowship for 13 religious categories (average in minutes) (Source: NCS, University of Lausanne 2008)

singing per celebration; and the Sufi fellowships (included in the Muslim category). ${ }^{10}$

\section{Sermon}

The sermon, for all the groups, is the shortest part of their celebration. Two poles emerge, however, with groups where the time for the sermon is marginal and those where it nevertheless represents an important part of the ritual. At one pole, the Baha'i have only a brief address of about $1 \mathrm{~min}$ on average; Catholic priests speak for $6 \mathrm{~min}$; Jewish rabbis $12 \mathrm{~min}$, etc. At the other pole are the groups sprung from

\footnotetext{
${ }^{10}$ The Muslims sing from 1 to $2 \mathrm{~min}$ in their celebration if we take the call to prayer into account. For many Muslims, the practice of music is forbidden (which is not the case for singing). The average for the denominational category is higher than these few minutes because of the Sufi fellowships.
} 
Protestantism, where preaching takes on a central character and occupies slightly less than one-third of the celebration time.

\section{Fellowship}

Concerning fellowship, it is notable that the longer the ceremony is, the more time the worshipers spend together. An Orthodox Christian who has just spent an average of two and a half hours in praise spends another hour with his or her coreligionists in informal discussion. At the other extreme, Catholics who have spent on average $54 \mathrm{~min}$ in the celebration spend only slightly more than a quarter of an hour in fellowship. The length of the celebration and that of the time spent informally by the worshipers indicates the type of community. For the groups with a population with a strong immigrant background, the community represents an important center for networking. The celebration is longer, with a greater formal and informal participation of the members. For the others, the celebration is primarily a practice before being a community of fellowship.

Using simple and comparable elements, we can thus analyze and compare apart from any theological considerations - the cultural production of very diverse religious traditions. In principle - for lack of space we do not go into these questions here - it is also possible to then explain these differences through various cultural, structural, and historical factors.

\section{Conclusion}

In this chapter, we have shown that existing problems and issues when studying religious diversity may be tackled with a new methodology that combines a full census and a national congregation study (NCS). Our claim has been that when this method is used, all religious traditions may be compared in a great many dimensions of religious diversity and in an extended geographic region. The data thus gathered may illuminate both diversity and pluralism and allow for both description and explanation of the phenomena observed. The study we have described has analyzed the organizational, geographic, structural, and cultural diversity, as well as aspects of the religious pluralism, of the whole range of religious traditions in Switzerland. This study has led to an entire set of original results, hitherto never observed. Our focus in this chapter has been to present the methodology and some exemplary results. Further publications will present these results in much more depth and will describe various contexts. We hope that other researchers will follow up on this methodology in order to complement all local and regional mapping studies with such national investigations, thus completing our knowledge of the fascinating topic of the diversity of religious diversity. 


\section{References}

AAPOR (American Association for Public Opinion Research). 2011. Standard definitions: Final dispositions of case codes and outcome rates for surveys, 7th ed. Deerfield: AAPOR.

Ahlin, Lars, Jørn Borup, Marianne Qvortrup Fibiger, Lene Kühle, Viggo Mortensen, and René Dybdal Pedersen. 2012. Religious diversity and pluralism: Empirical data and theoretical reflections from the Danish pluralism project. Journal of Contemporary Religion 27: 403-418.

Al-Azmeh, Aziz, and Effie Fokas (eds.). 2007. Islam in Europe. Diversity, identity and influence. Cambridge: Cambridge University Press.

Ammerman, Nancy T. 2005. Pillars of faith: American congregations and their partners. Berkeley: University of California Press.

Baumann, Christoph P. (ed.). 2000. Religionen in Basel-Stadt und Basel-Landschaft. Basel: Manava-Verlag.

Baumann, Martin. 2004. Organising Hindu temples in Europe, the case of Tamil migrants from Sri Lanka. In Unterwegs Neue Pfade in der Religionswissenschaft. Festschrift in honour of Michael Pye on his 65th birthday, ed. Christoph Kleine, Monika Schrimpf, and Katja Triplett, 379-391. München: Biblion.

Baumann, Martin. 2009. Templeisation: Continuity and change of Hindu traditions in Diaspora. Journal of Religion in Europe 2: 149-179.

Baumann, Martin, and Jörg Stolz (eds.). 2007. Eine Schweiz - viele Religionen: Risiken und Chancen des Zusammenlebens. Bielefeld: Transcript.

Baumann, Martin, Brigitte Luchesi, and Annette Wilke (eds.). 2003. Tempel und Tamilen in zweiter Heimat. Würzburg: Ergon.

Beckford, James A. 1999. The management of religious diversity in England and Wales with special reference to prison chaplaincy. International Journal on Multicultural Societies 1: $55-66$.

Beckford, James A. 2003. Social theory and religion. Cambridge: Cambridge University Press.

Behling, Orlando, and Kenneth S. Law. 2000. Translating questionnaires and other research instruments: Problems and solutions. London: Sage Publications.

Behloul, Samuel M. 2012a. Religion or culture? The public relations and self-presentation strategies of Bosnian Muslims in Switzerland compared with other Muslims. In The Bosnian Diaspora. Integration in transnational communities, ed. Marko Valenta and Sabrina P. Ramet, 301-318. London: Ashgate.

Behloul, Samuel M. 2012b. Negotiating the 'Genuine' religion: Muslim Diaspora communities in the context of the western understanding of religion. Journal of Muslims in Europe 1: 7-26.

Bochinger, Christoph (ed.). 2012. Religionen, Staat und Gesellschaft. Die Schweiz zwischen Säkularisierung und religiöser Vielfalt. Zurich: Librio.

Bouma, Gary D. 1997. Religion and cultural plurality in Australia. In Many religions, all Australian: Religious settlement, identity and cultural diversity, ed. Gary D. Bouma, 95-108. Kew: The Christian Research Association.

Bouma, Gary D., Rod Ling, and Douglas Pratt. 2010. Religious diversity in Southeast Asia and the Pacific: National case studies. Heidelberg: Springer.

Bovay, Claude. 1997. L'évolution de l'appartenance religieuse et confessionnelle en Suisse Recensement fédéral de la population 1990. Bern: Federal Statistical Office.

Bovay, Claude. 2004. Le paysage religieux en Suisse, Recensement fédéral de la population 2000. Neuchatel: FSO. http://www.bfs.admin.ch/bfs/portal/fr/index/themen/01/22/publ.html? publicationID $=1615$

Chaves, Mark. 2004. Congregations in America. Cambridge: Harvard University Press.

Chaves, Mark, and Shawna L. Anderson. 2008. Continuity and change in American congregations: Introducing the second wave of the National Congregations Study. Sociology of Religion 69: 415-440. 
Chaves, Mark, Mary E. Konieczny, Beyerlien Kraig, and Emily Barman. 1999. The National Congregations Study: Background, methods and selected results. Journal for the Scientific Study of Religion 38: 458-477.

Cnaan, Ram A., and Stephanie Boddie. 2001. Philadelphia census of congregations and their involvement in social service delivery. Social Service Review 75: 559-580.

Cnaan, Ram A., and Bob Wineburg. 2009. The united way of Delaware. Wilmington: Penn Social Policy and Practice \& The University of North Carolina.

Eck, L. Diana. 2001. A new religious America: How a 'Christian Country' has become the world's most religiously diverse nation. San Francisco: Harper Collins Publishers.

Ferrari, Silvio, and Sabrina Pastorelli (eds.). 2012. Religion in public space. A European perspective. London: Ashgate.

Forsyth, Barbara H., Martha Stapleton Kudela, Kerry Levin, Deirdre Lawrence, and Gordon B. Willis. 2007. Methods for translating an English-language survey questionnaire on tobacco use into Mandarin, Cantonese, Korean, and Vietnamese. Field Methods 19: 264-283.

Frégosi, Franck. 2008. Penser l’islam dans la laïcité : Les musulmans de France et la République. Paris: Fayard.

FSO (Federal Statistics Office). 2012. Indicateurs du marché du travail 2012. Neuchatel: FSO. http://www.bfs.admin.ch/bfs/portal/fr/index/themen/03/22/publ.html?publicationID=4851

Göle, N. 2011. Islam in Europe: The lure of fundamentalism and the allure of cosmopolitanism. Princeton: Markus Wiener Publishers.

Heelas, Paul, and Linda Woodhead. 2005a. Kendal, Cumbria : A spiritual laboratory. CeNtreWoRds 4: 17-26.

Heelas, Paul, and Linda Woodhead (eds.). 2005b. The spiritual revolution: Why religion is giving way to spirituality. London: Blackwell.

Heino, Harri. 1997. Mihin Suomi Tänään Uskoo. Porvoo: WSOY.

Hernández, Edwin I., Neil R. Carlson, Nathan Medeiros-Ward, Armanda Steck, and Lori Verspoor (eds.). 2008. Gatherins of hope. How religious congregations contribute to the quality of life in Kent county. Grand Rapids: Center for Social Research of Calvin College.

Hero, Markus, Volkhard Krech, and Helmut Zander. 2008. Religiöse Vielfalt in NordrheinWestfalen: Empirische Befunde und Perspektiven der Globalisierung vor Ort. Paderborn: F. Schöningh.

Humbert, Claude-Alain. 2004. Religionsführer Zürich: 370 Kirchen, Religiös-spirituelle Gruppierungen, Zentren und Weltanschauliche Bewegungen der Stadt Zürich. Zurich: Orell Füssli.

Husistein, Roger. 2007. Katholische Kirche in der Schweiz. Zahlen - Fakten - Entwicklungen 1996-2005. St-Gallen: SPI.

Jeavons, Thomas H. 1998. Identifying characteristics of 'religious' organizations: An exploratory proposal. In Sacred companies: Organizational aspects of religion and religious aspects of organizations, ed. Nicholas J. Demerath, Peter Dobkin Hall, Terry Schmitt, and Rhis H. Williams, 79-94. Oxford: Oxford University Press.

Kay, William K., and Anne E. Dyer (eds.). 2011. Pentecostalism in Europe. Leiden: Brill.

Knott, Kim. 2009. Becoming a 'Faith Community': British Hindus, identity, and the politics of representation. Journal of Religion in Europe 2: 85-114.

Martikainen, Tuomas. 2004. Immigrant religions in local society: Historical and contemporary perspectives in the city of Turku. Åbo: Åbo Akademy University Press.

Marzi, Eva. 2008. Confrontation d'une théorie au terrain. Le cas de la communauté religieuse (Bachelor Dissertation). Geneva: Sociology Department, University of Geneva.

Mayer, Jean-François. 1993. Les nouvelles voies spirituelles. Enquête sur la religiosité parallèle en Suisse, Pluralisme culturel et identité nationale. Lausanne: L'Age d'homme.

Mcpherson, J. Miller, and Thomas Rotolo. 1995. Measuring the composition of voluntary groups: A multitrait, multimethod analysis. Social Forces 73: 1097-1115.

Monnot, Christophe (ed.). 2013a. La Suisse des mosquées. Derrière le voile de l' unité musulmane. Geneva: Labor et Fides. 
Monnot, Christophe. 2013b. Croire ensemble. Analyse institutionnelle du paysage religieux en Suisse. Zurich: Seismo.

NCS (National Congregations Study). 2008. DARIS: Data and Research Information Services. http://forsdata.unil.ch/data/themesearch.asp?lang=e

Pahud de Mortanges, René. 2007. System und Entwicklungstendenzen des Religionsverfassungsrechts der Schweiz und des Fürstentums Liechtenstein. Zeitschrift für Evangelisches Kirchenrecht 52: 495-523.

Park, Robert E., Ernest W. Burgess, and Roderick D. Mackenzie. 1925. The city. Chicago: University of Chicago Press.

Pollack, Detlef. 2008. Religious change in Europe: Theoretical considerations and empirical findings. Social Compass 55: 168-186.

Rademacher, Stefan. 2007. Neue Religiöse Gemeinschaften: Viele Antworten auf ein sich verändernde Welt. In Eine Schweiz, viele Religionen. Risiken und Chancen des Zusammenlebens, ed. Martin Baumann and Jörg Stolz, 238-255. Bielefeld: Transcript.

Salzbrunn, Monika. 2012. Vielfalt/Diversity/Diversité. Soziologische Revue 35: 375-394.

Stolz, Jörg. 2010. A silent battle. Theorizing the effects of competition between churches and secular institutions. Review of Religious Research 51: 253-276.

Stolz, Jörg, and Martin Baumann. 2007. Religiöse Vielfalt: Kulturelle, soziale und individuelle Formen. In Eine Schweiz, viele Religionen. Risiken und Chancen des Zusammenlebens, ed. Martin Baumann and Jörg Stolz, 21-38. Bielefeld: Transcript.

Stolz, Jörg, Mark Chaves, Christophe Monnot, and Laurent Amiotte-Suchet. 2011. Die religiösen Gemeinschaften in der Schweiz: Eigenschaften, Aktivitäten, Entwicklung. Bern: Swiss National Science Foundation.

Trisconi di Bernardi, Michela. 2006. Repertorio delle Religioni, Panorama Religioso e Spirituale del Cantone Ticino. Bellinzona: Dipartimento delle instituzion.

Vertovec, Steven. 2007. Super-diversity and its implications. Ethnic and Racial Studies 30: 1024-1054.

Wihtol de Wenden, Catherine. 2004. Ville, religion et immigration. Les Annales de la recherche urbaine 96: 115-116.

Willaime, Jean-Paul. 2004. Europe et religions: les enjeux du XXI siècle. Paris: Fayard.

Wind, James P., and James W. Lewis (eds.). 1994. American congregations volume 1: Portraits of twelve religious communities. Chicago: University of Chicago Press.

Wirth, L. 1928. The Ghetto. Chicago: University of Chicago Press.

Woodhead, Linda, Mathew Guest, and Karin Tusting. 2004. Congregational studies: Taking stock. In Congregational studies in the UK: Christianity in a post-christian context, ed. Linda Woodhead, Mathew Guest, and Karin Tusting, 1-23. Aldershot: Ashgate. 